\title{
SAQQARA: SOME REMARKS ON FLORA FROM FUNERARY CONTEXT
}

\author{
Malgorzata Radomska \\ Institute of Mediterranean and Oriental Cultures, Polish Academy of Sciences, Nowy Świat 72, \\ 00-330Warszawa, Poland,e-mail:malrad@wp.pl
}

\begin{abstract}
An extensive Ptolemaic cemetery west of the Step Pyramid in Saqqara (Egypt), excavated since 1987 by a Polish mission headed by Karol Myśliwiec, has inspired the present study. Over 500 burials have been found so far in strata overlying the Old Kingdom necropolis. The aim of the paper is to present the plant remains discovered in burial contexts in 1987-2012 in the so-called Upper Necropolis. It emphasizes the results of their archaeobotanical analyses. The effects of research on plant remains from the Lower Necropolis are presented here to be used as a 2000 years older comparative material.
\end{abstract}

Key words: Saqqara, burial, flora

\section{INTRODUCTION}

The term "Memphite necropolis", which is current in the literature on the subject and in the awareness of most scholars of Ancient Egypt, refers to the biggest burial ground of the ancient world, extending from Abu Roash in the north to Medum in the south. Modern Saqqara, the name of which was first used to designate the cemeteries of Memphis on a map of Egypt in $1743 \mathrm{AD}$, constitutes the central part of the Memphite necropolis. It covers an area approximately $6 \mathrm{~km}$ long and more than $1.5 \mathrm{~km}$ wide and is located c. $19 \mathrm{~km}$ to the south of modern Cairo (Fig. 1).

Archaeological research by the Polish-Egyptian mission carried out to the west of the pyramid of Djoser at Saqqara from 1987 has led to the identification of two cemeteries: the so-called Lower Necropolis from the Old Kingdom (Myśliwiec et al., 2004; Myśliwiec \& Kuraszkiewicz et al., 2010) and the superposed Upper Necropolis from the Ptolemaic Period (Radomska et al., 2008; Kaczmarek et al., 2008) (Fig. 2). The multi-disciplinary approach to the investigations called for geoarchaeological studies designed to reconstruct the processes shaping the natural landscape in Saqqara. One of the analyses concerned floral remains from funerary contexts. Although numerous garden and field plants are represented as food offerings for the deceased on the walls of individual cult chapels, an archaeobotanical study of the actual finds of vegetables, fruits and other plants from burial contexts has facilitated a better understanding and reconstruction of the flora of the relevant periods.

\section{Environment of the region}

Through studies on the Ptolemaic Memphis conducted by D. Thompson and on Greek papyri by E. Wipszycka, our knowledge of the natural environment of the Memphite necropolis in the times of the Ptolemy's has been enriched (Thompson, 1988; Wipszycka, 2010).

The town was composed of two separate but interconnected parts: the valley with the temple enclosure and the extensive cemetery on the desert plateau to the west. The town in the valley with its embankments, temples and ethnically differentiated districts was separated by the canal from the steeply rising edge of the sand-covered plateau (Thompson, 1988). The location of Memphis was determined by the presence of natural water springs, (i.e. then the river-bed of the Nile) meeting the demands for water of the settled population as well as the needs of agriculture within the borders of the city. Embankments secured the city center against the annual Nile inundation (Thompson, 1988).

At the time of the Ptolemy's the landscape around Memphis was full of thick palm groves, orchards and clumps of wild trees. Common fruit trees included fig trees, primarily date and dum palms. All of these, as well as the walnut and mulberry occur in receipts from the Serapeum (Thompson, 1988). The sycamore, persea and acacia trees add to the rich picture of Memphite gardens.

On the base of papyrus sources, E. Wipszycka stated that, among the cultivated plants, the wheat was predominant. The species identified as Triticum dicoccum is referred to by the Greek name of olyra - spelt wheat in the papyri (Wipszycka, 2010). Barley (Hordeum vulgare L.) was used mainly as animal fodder and to make beer. Wheat and other cut plants grew in the valley outside the city limits, whereas the vineyards, orchards and gardens were situated inside the town. Pasture crops, including clover, fenugreek and grass for straw, were general grown in the region, and lettuce, cabbage, chickpeas, fennel, garlic and cumin - near the canal. As stated by $\mathrm{D}$. Thompson the location of some of the vineyards 

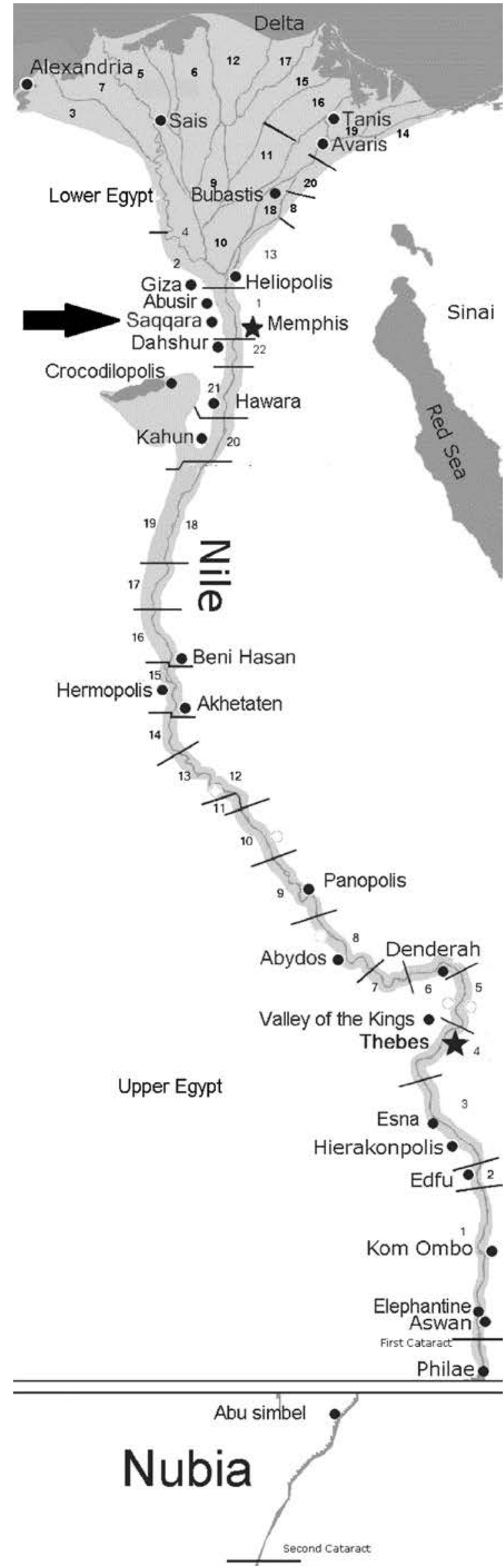

Fig. 1. Map of Egypt: black arrow to Saqqara site. is given in the Hibeh Papyrus and in documents from Zeno's archive mentioning a vineyard down on the banks of the Nile as well as others to the west of the town, near the canal (Thompson, 1988). Property documents of the Memphite community mention vineyards and orchards situated in these western peripheries and funerary gardens on the lower level of the necropolis where their use has been more profitable.

\section{MATERIAL AND METHODS}

Over one hundred (123 samples) botanical remains originating from the Upper Necropolis (Ptolemaic Period), located to the west side of the pyramid of Djoser at Saqqara (Egypt), were subjected to laboratory examination. All of them were found in the burial contexts in the years 19872012.

Study on plants consisted of a few stages: 1) fieldwork including exploration of burials in situ; 2) pre-selection of plant material; 3) photographic documentation of all finds; 4) macroscopic, microscopic, microbiological and microchemical laboratory analysis of textile samples; 5) palaeobotanical analysis of plant remains; 6) presentation of the results of research on the material from the Old Kingdom as a comparison.

\section{RESULTS AND DISCUSSION}

\section{The Lower Necropolis (Old Kingdom)}

Pottery analyses, including the study on the contents of ritual vessels by $\mathrm{T}$. Rzeuska have contributed to a recreation of successive stages of funerary rites from the Old Kingdom Period (Rzeuska, 2006). Deposits of ash-filled beer jars discovered in the burial shafts were identified as being part of these rites and a paleobotanical examination of the remains determined the species structure of these assemblages (Rzeuska \& Zieliński, 2004; Rzeuska, 2006). The botanical remains in the ashes of the beer jars were what were left of a pyre. The burned offerings included mainly agricultural products and grain was here in predominance (Rzeuska, 2006). The table below (Table 1, left side) presents the species of plants of the ashes in the seven jars dated to the Old Kingdom. A comparative analysis was carried out for plant material from 123 burials dated to the Ptolemaic Period (Table 1 , right side).

A consideration of the results of archaeobotanical examination of seven jars filled with ashes from this cemetery led to the distinguishing of two main types of offering pyres: summer and winter (Rzeuska, 2006). The species of plants burned as offerings in the summer obviously differed from those burned in the winter months. The identification of marker species suggested a definite season of the burials (Rzeuska, 2006). When grain in the offerings was accompanied by seeds of weeds and wild grain, without chaff or thorns, meaning that only threshed grain was being burned in offering, it was quite obvious that the offering had been made in winter. In this case the fuel used for the purpose was mainly palm wood. In the other kind of burned offering straw was the fuel. Bits of straw could be found among the ashes. Burning armfuls of grain of all kinds was easy enough without adding any other kind of wood as fuel. Such an offering was possible in late spring and summer (from March to June), 


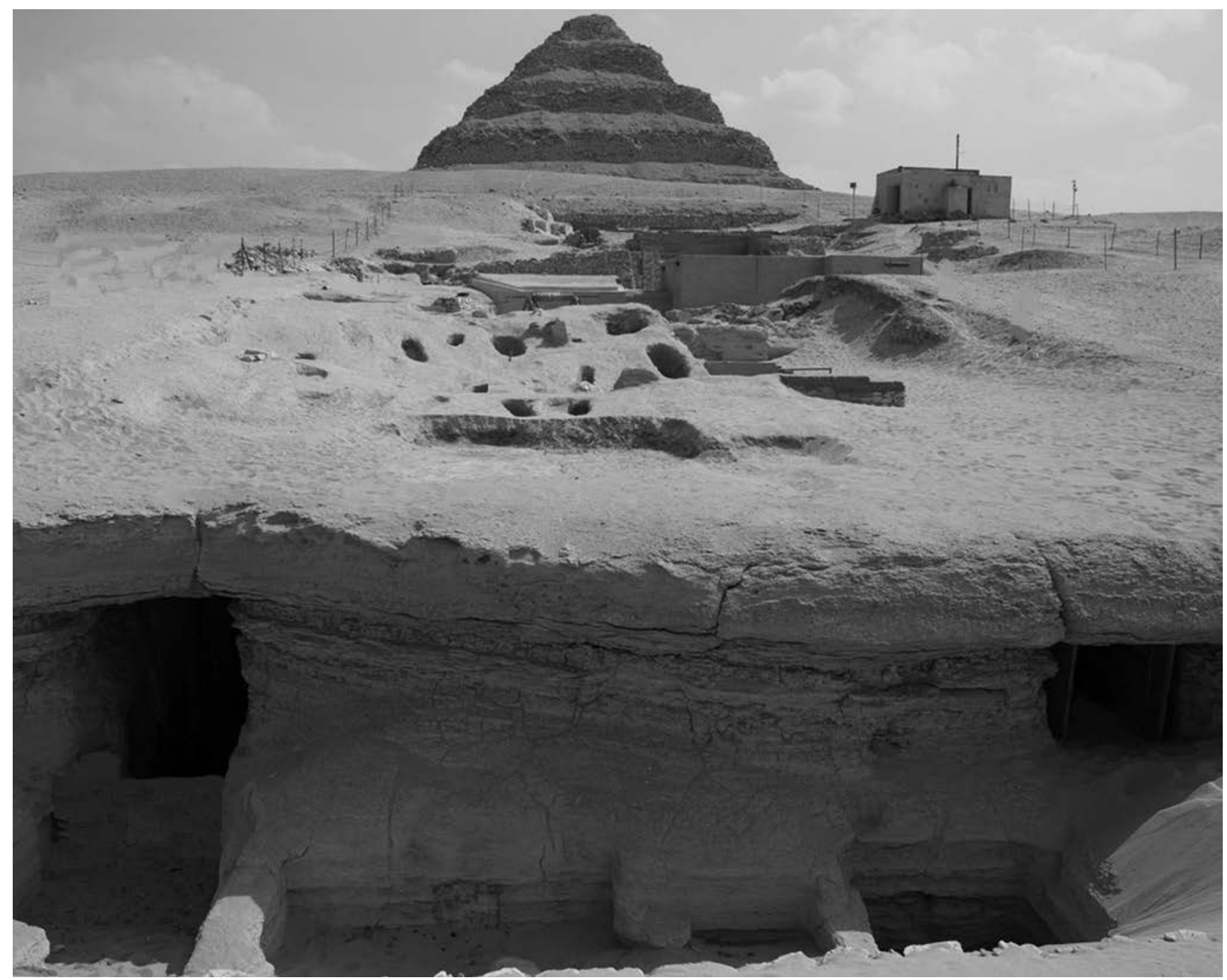

Fig. 2. The Upper and Lower Necropolises west of the Step Pyramid in Saqqara (phot. W. Wojciechowski).

when grain was growing in the fields (Rzeuska, 2006). According to T. Rzeuska's reconstruction of the rite, a pile of fruit, including figs, "Tiger Nuts" and grapes, as well as flowers, grain and armfuls of the plants were piled up in a bowl and lighted. Once the plants had burned, the ashes along with unburned parts of plants and broken sherds were collected into a jar and sealed (Rzeuska, 2006).

In the Old Kingdom necropolis botanical remains were found also in the form of wooden or reed coffins and mats, as well as wooden headrests and staffs, which formed part of the grave furnishings (Myśliwiec \& Kuraszkiewicz et al., 2010; Myśliwiec 2011).

\section{The Upper Necropolis (Ptolemaic Period)}

Burials from the Upper Necropolis were largely looted and damaged already in antiquity. Also the funerary equipment was significantly poorer due to the fact of mostly the middle and lower classes buried here. Despite the limitations resulting from the nature of available data, in a limited number of cases it was still possible to record and identify the spe- cies of plants that were deposited with the deceased in the graves.

Botanical remains were noted in 123 of the 503 burials discovered till the last season in 2012. Coffins are a major category among the finds. Plants were also identified inside the mummies, and in the wreaths, garlands, bouquets or as vegetables deposited with the body of the deceased. Finally, there is the evidence of constituent parts of the grave furnishings, such as wooden canopic boxes, figures, and plaited baskets.

\section{Coffins}

Archaeobotanical examination of 90 coffins identified the material used in their production (Kowalska 2003; Radomska et al., 2008; Myśliwiec \& Kuraszkiewicz et al., 2010). In 68 cases the coffins were made of large pieces of cedar wood (Cedrus libani) (Fig. 3). 18 coffins found in the Upper Necropolis, but dated to the Old Kingdom, were made of reeds and 4 of plaited palm leaves. In two cases the burials were covered with mats plaited of fiber and ribs of palm 


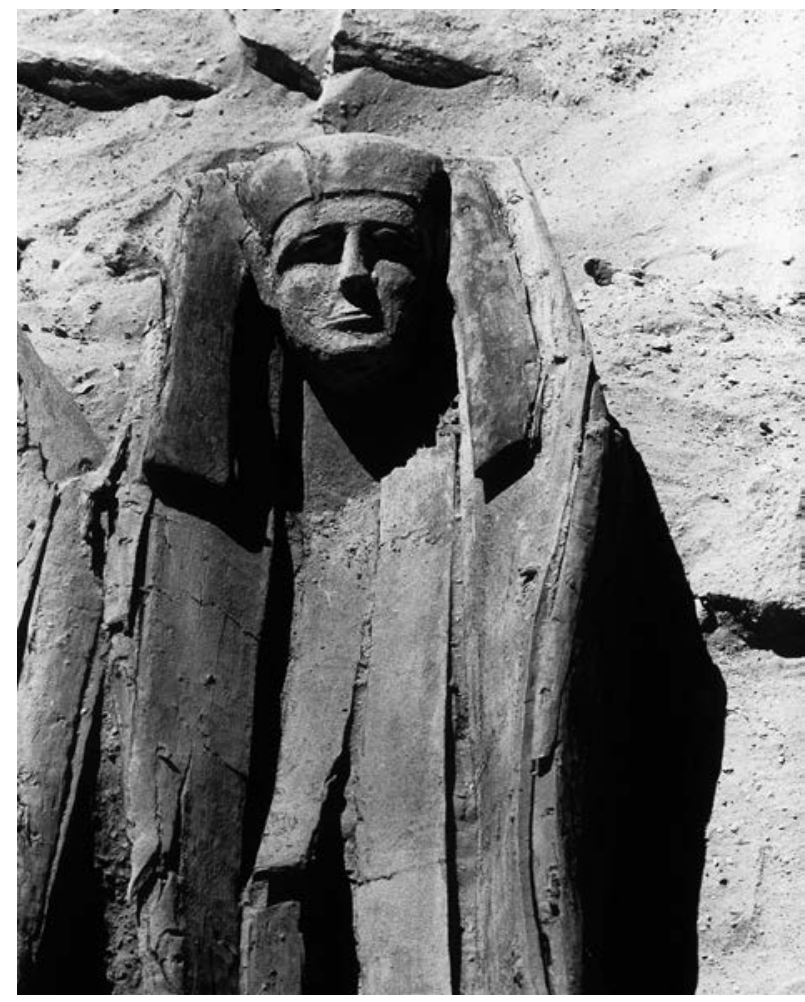

Fig. 3. Burial 335: wooden coffin (phot. M. Jawornicki).

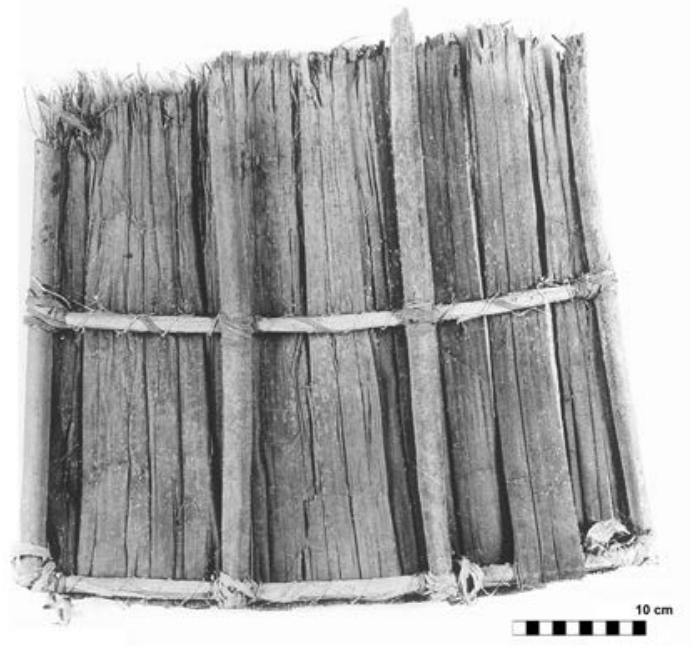

Fig. 4. Palm leaves mat from Burial 241 (phot. M. Jawornicki).

leaves (Jarids palm) held together with rope made of plied papyrus fiber (Cyperus papirus L.) (Fig. 4).

\section{Bandages}

Examination under the microscope of 17 samples of mummy bandages identified linen (Linum usitatissimum L.) as the material used in all cases for the production of shrouds and for the inner and outer bandages (Kaczmarek et al., 2008) (Fig. 5). Since the textile serve as a support for the cartonnage, the pigments used for their decoration were also analyzed. Laboratory researches on such pigment found on one
Table 1

Paleobotanical analysis of ashes from seven beer jars found in the Lower Necropolis (Old Kingdom Period from Rzeuska, 2006) and species of plants identified in the contexts of 123 burials discovered in the Upper Necropolis

(Ptolemaic Period) in Saqqara

\begin{tabular}{|c|c|}
\hline Lower Necropolis & Upper Necropolis \\
\hline & Abies cilicica (fir) \\
\hline Acacia sp. (acacia) & Acacia sp. (acacia) \\
\hline \multicolumn{2}{|l|}{ Agropyron repens (quitch) } \\
\hline & Allium cepa L. (onion) \\
\hline & Allium kurrat (leek) \\
\hline \multicolumn{2}{|l|}{ Apium graveolens L. (celery) } \\
\hline \multicolumn{2}{|l|}{ Avena fatua L. (oats) } \\
\hline \multicolumn{2}{|l|}{ Avena sp. (oats) } \\
\hline \multicolumn{2}{|l|}{ Balanites aegyptiaca L. (balanos) } \\
\hline \multicolumn{2}{|l|}{ Cajanus cajan L. (pigeonpea) } \\
\hline \multicolumn{2}{|l|}{ Calendula officinalis (marigold) } \\
\hline \multicolumn{2}{|l|}{ Carthamus tinctorius L. (safflower) } \\
\hline & Cedrus libani (cedar) \\
\hline \multicolumn{2}{|l|}{ Celosia sp. (cockscomb) } \\
\hline \multicolumn{2}{|l|}{ Cichorium sp. (chicory) } \\
\hline \multicolumn{2}{|l|}{ Cyperus esculentus L. (tigernut) } \\
\hline & Cyperus papyrus L. (papyrus) \\
\hline Ficus carica L. (fig) & Ficus carica L. (fig) \\
\hline \multicolumn{2}{|l|}{ Hordeum distichum L. (barley) } \\
\hline & Hordeum vulagare L. (barley) \\
\hline & Jarids palm (palm) \\
\hline Linum usitatissimum L. (flax) & Linum usitatissimum L. (flax) \\
\hline \multicolumn{2}{|l|}{ Lupinus sp. (lupine) } \\
\hline \multicolumn{2}{|l|}{$\begin{array}{l}\text { Matricaria chamomila L. (chamo- } \\
\text { mile) }\end{array}$} \\
\hline \multicolumn{2}{|l|}{ Nigella sativa L. (black cumin) } \\
\hline \multicolumn{2}{|l|}{ Ochradenus baccatus (taily weed) } \\
\hline \multicolumn{2}{|l|}{ Papaver sp. (poppy) } \\
\hline \multicolumn{2}{|l|}{$\begin{array}{l}\text { Phalaris paradoxa L. (awned ca- } \\
\text { nary grass) }\end{array}$} \\
\hline \multirow[t]{2}{*}{ Phoenix dactylifera L. (date-palm) } & Phoenix dactylifera L. (date-palm) \\
\hline & Punica granatum L. (pomegranate) \\
\hline \multicolumn{2}{|l|}{ Reseda odorata (sweet mignonette) } \\
\hline \multicolumn{2}{|l|}{$\begin{array}{l}\text { Scorpiurus muricatus (prickly } \\
\text { caterpillar) }\end{array}$} \\
\hline \multicolumn{2}{|l|}{ Sorghum sp. (sorgo) } \\
\hline Triticum dicoccum (emmer wheat) & Triticum dicoccum (emmer wheat) \\
\hline \multicolumn{2}{|l|}{$\begin{array}{l}\text { Triticum monococcum (Einkorn } \\
\text { wheat) }\end{array}$} \\
\hline Vitis vinifera L. (grapes) & Vitis vinifera L. (grapes) \\
\hline $\begin{array}{l}\text { Zizyphus spina Christi L. } \\
\text { (Christ-thorn) }\end{array}$ & \\
\hline
\end{tabular}

of the burials (B. 406) have confirmed the presence of plant seeds in their composition. It may be assumed that the pigment binder was a plant gum originating from an indeterminable species of acacia (Acacia $s p$.), while the protein was used as a binder for the carbonate layer, that is, the plaster (Kaczmarek et al., 2008). 


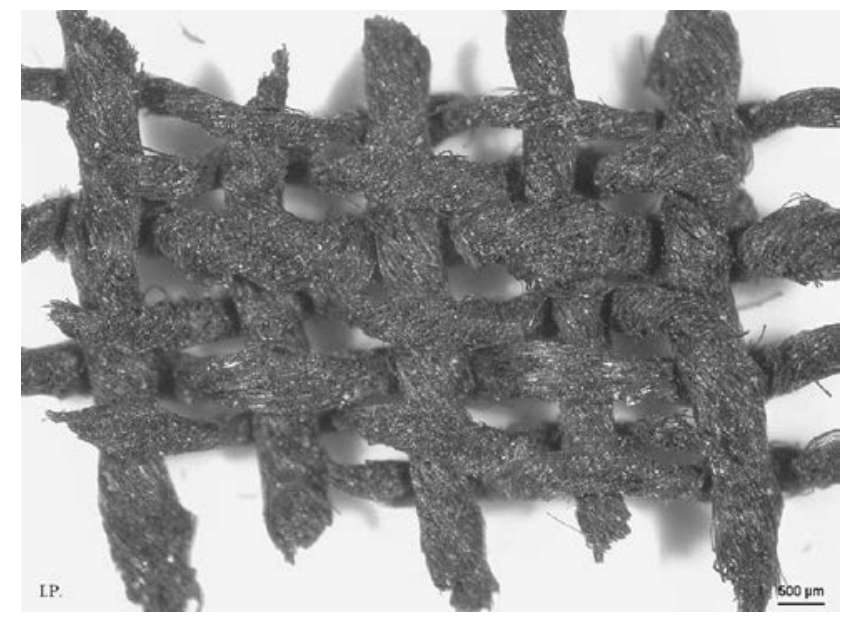

Fig. 5. Linen threads (bandage from Burial 459) impregnated with substances used in the mummification process (phot. I. Pannenko).

\section{Sticks inside the bodies}

Sticks were found inserted into the bodies in the case of five burials: in the skull - in two instances (B. 14, 35), and lengthwise along the body - in three others (B. 452, 563, 566) (Radomska et al., 2008). This was done in the course of the mummification, in an effort to re-connect the head of the deceased with the rest of the body and to stiffen the corpse to retain an anthropomorphic shape. The sticks could be placed both on the body and inserted between the layers of bandages. This solution was useful particularly when the corpse was not interred in a coffin. In all examples the sticks represent palm leaf ribs (Jarids palm).

\section{Wreaths}

In the case of 24 mummies the dead had wreath placed on his head (Radomska et al., 2008). In 13 instances (B. 8, 25, $26,34,35,47,51,80,358,359,406,477,486)$ wreaths were made of rope of date-palm leaf fiber (Phoenix dactyli-fera L.) wrapped in the blades of grass and covered with bandages wrapped around this core. Five wreaths (B. 216, 217, 463, $494,495)$ were plaited of reeds and wrapped diagonally with bandages (Fig. 6). Three (B. 451, 459, 478) made use probably of barley stems (Hordeum vulgare L.) wrapped in bandages and additionally in linen string. The wreath in one of the burials (B. 466) had been made of barley straw in a slightly different technique than all the other wreaths found in the necropolis. Here the straw was first wrapped obliquely with a few stalks of the straw and then with bandages (Fig. 7). The two other wreaths (B. 498, 504) were plaited from bulrush fiber, wrapped in bandages and additionally tied with thread (Fig. 8).

Flowers and other plants placed in the grave in farewell are known from many periods and cultures. It may be assumed that wreaths were submitted in the same character. But what was the significance of this kind of wreaths specifically? The custom of decorating the head of a deceased with a wreath may be related to the so-called crown of justification, also referred to as a crown of victory (Barguet, 1967). The wreath can be probably associated with Osiris and is a crown

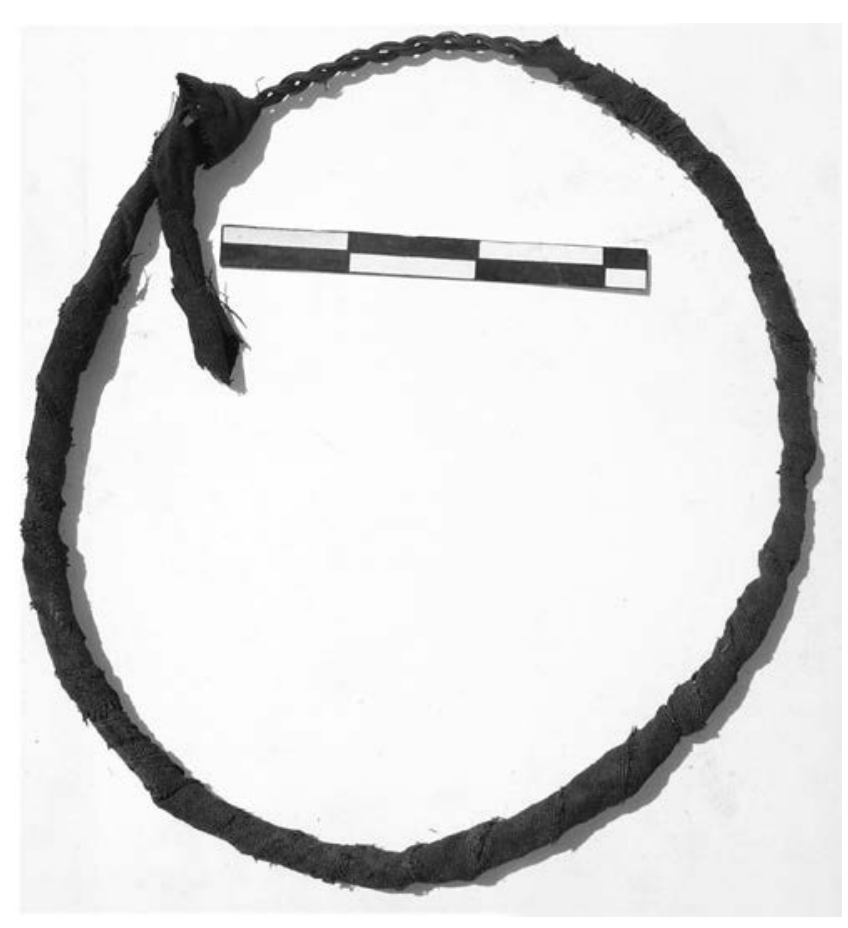

Fig. 6. Wreath from Burial 495 plaited of reeds and wrapped with bandages. Linear scale is $10 \mathrm{~cm}$ (Phot. M. Radomska).

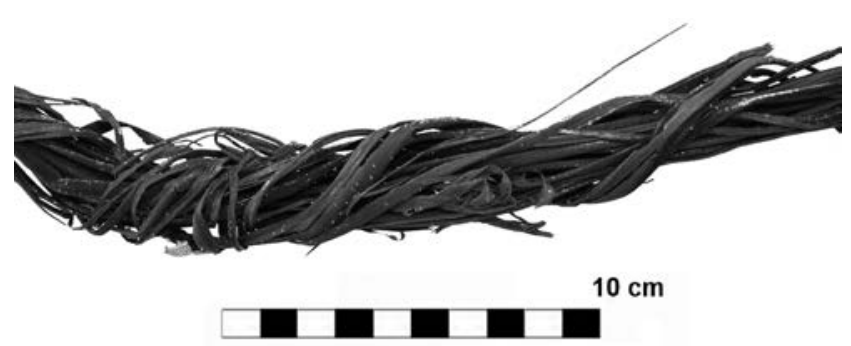

Fig. 7. The tangle of the wreath from Burial 466 made of barley straw (phot. M. Radomska).

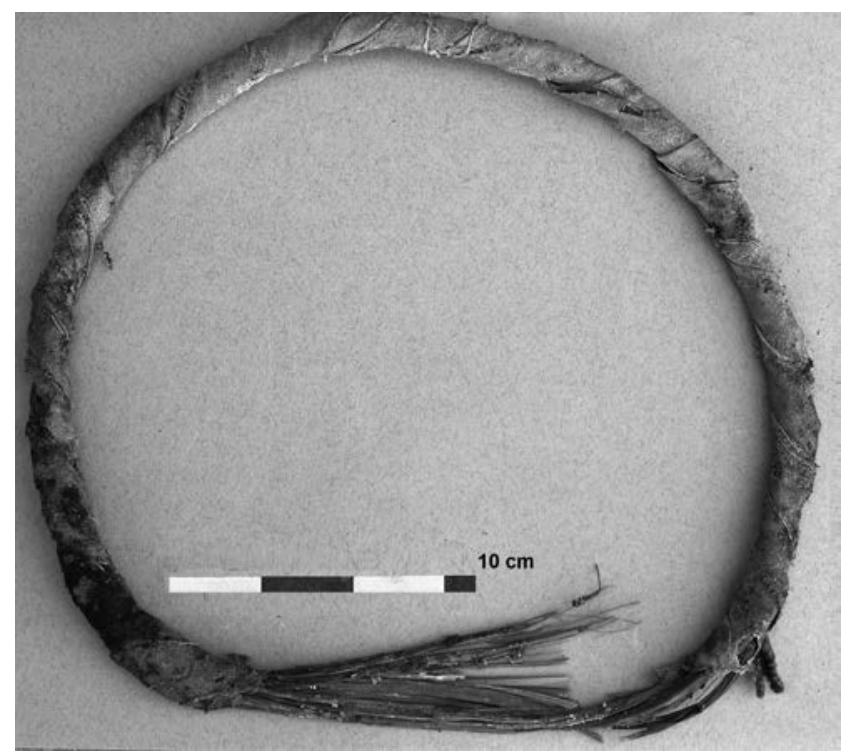

Fig. 8. Wreath from Burial 498 plaited from bulrush fiber (phot. M. Radomska). 


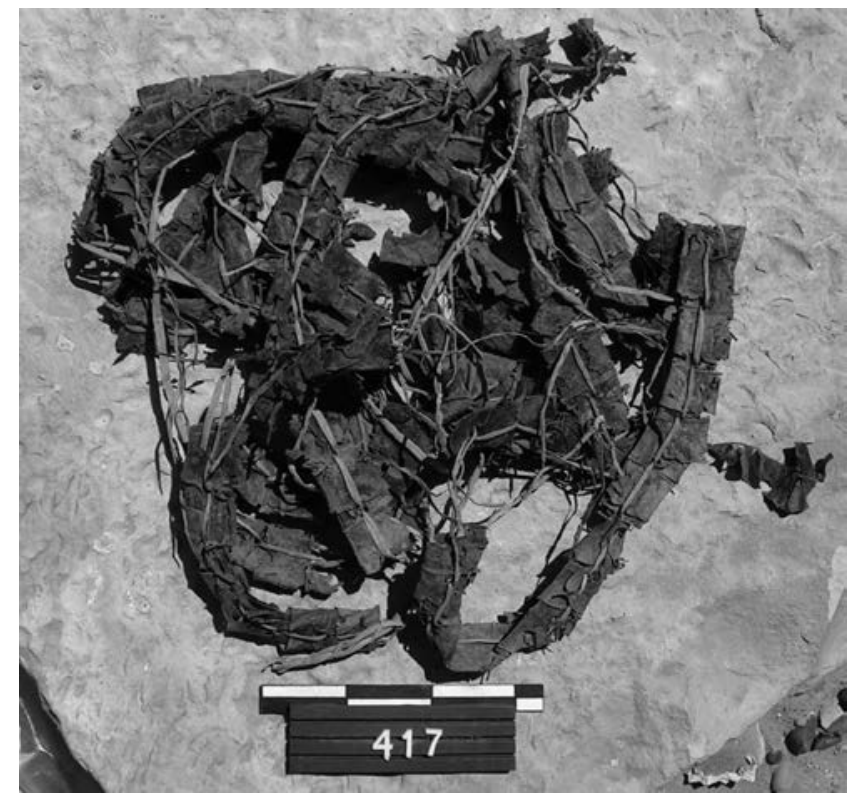

Fig. 9. Plant garlands found near the mummy (Burial 417). Linear scale is $10 \mathrm{~cm}$ (phot. P. Lelek).

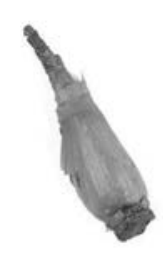

B. 417

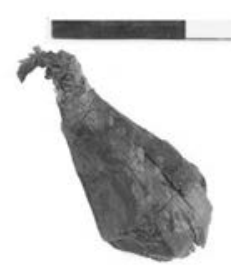

B. 423

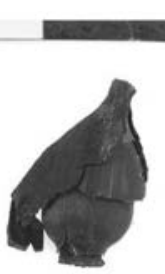

B. 466

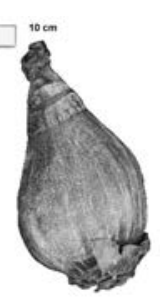

B. 495
Fig. 10. Onions from the burial contexts (phot. M. Radomska).

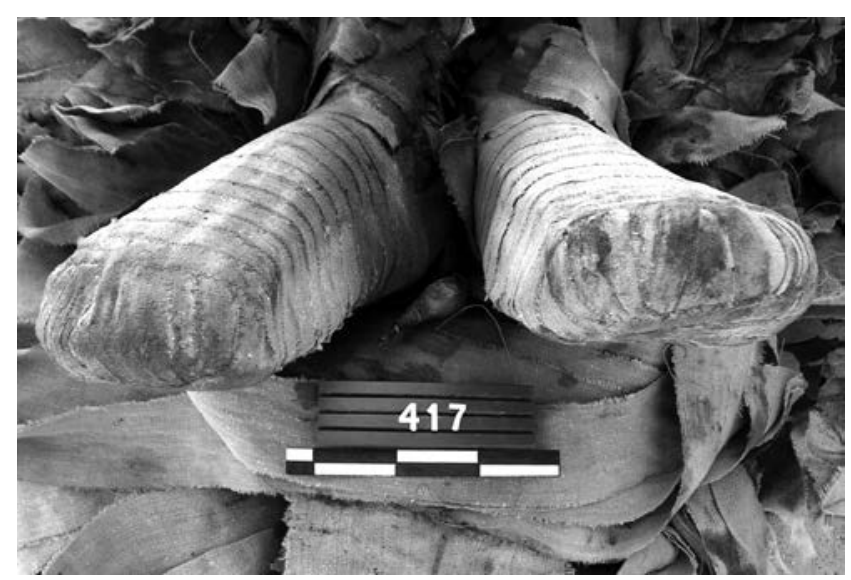

Fig. 11. An onion between the feet of the deceased (Burial 417). Linear scale is $10 \mathrm{~cm}$ (phot. I. Kozieradzka).

symbolizing victory over the enemies. A. Schweitzer suggested a probable association of the plant wreath with such crown pointing to a like depiction on a vignette from the Chapter XIX of the Book of the Dead (Schweitzer, 1992). The ritual of offering of the crown was accompanied by the words: "the one justified by voice", what should undoubtedly be considered as an epithet of the deceased. Placing the wreath vel crown on the head of the deceased in this ritual could be intended to symbolize favorable judgment at the Court of Osiris, meaning that the deceased had given the right answers to questions posed by the judges and could pass into the life in the underworld. In the vignette the deceased is shown being handed such a wreath from the hands of a god (Barguet, 1967). The vegetal wreaths found with the mummies in the Upper Necropolis could have signified this particular rite taking place in the course of the funeral ceremonies.

\section{Garlands}

Vegetal garlands were discovered in the context of 8 burials (Radomska et al., 2008). In 5 cases (B. 8, 486, 494, $495,504)$ the mummies had been bound with them and in three (B. 406, 417, 526) - these lay near the bodies. Archaeobotanical examination identified the species of plants used in the production of seven of such garlands. In five cases a linen string (Linum usitatissimum L.) was wrapped with pomegranate leaves (Punica granatum L.) (Fig. 9), in one (B. 406) a date-palm leaves string (Phoenix dactylifera $\mathrm{L}$.) was used for the purpose and in another (B. 504) barley straw (Hordeum vulgare L.) was wrapped with fig leaves (Ficus carica L.).

The choice of plants was surely intentional. As stated by L. Manniche in her work on ancient Egyptian herbal, barley in the funerary rites evidently symbolized the resurrection of Osiris. Pomegranate leaves were equally symbolic, the pomegranate being a synonymous with fertility in the GraecoRoman world (Manniche, 1989).

\section{Flower bouquets}

Bouquets of dried flowers were found in two burials (B. 183, 417) (Radomska et al., 2008). The selection of flowers for the purpose must have been based on the symbolic importance of different species in the eyes of the Ancient Egyptians and not the beauty of the flowers themselves. Archaeobotanical examination of the remains of the two bouquets indicated the presence of papyrus stems (Cyperus papirus L.).

\section{Vegetables}

Onions were found in 4 burial contexts (B. 417, 423, 466, 495) (Radomska et al., 2008) (Fig. 10). In two cases (B. 417 and 495), they had been placed between the feet of the deceased, under the inner bandages (Fig. 11). One of the dead (B. 495) had another onion clasped in the palm of the left hand. A third example (B. 466) consisted of one onion under the flat right palm and wrapped in bandages together with it (Fig. 12) and another onion on the left foot, between the layers of bandages.

Archaeobotanical analysis of the onions identified them as a vegetal not floral species (Allium cepa L.). This choice must have been of symbolic significance. As suppose A. Niwiński, the floral onion symbolized hope for resurrection after death (Niwiński, 1993); the vegetal one had a much more prosaic role to play - its smell warded of snakes. One may consider in these cases fear of the serpent god Apopis and his role in the punishment of condemned souls at the Judgment of Osiris. The symbolic meaning of the vegetal onion for the protection of the soul as well as the bodily remains 


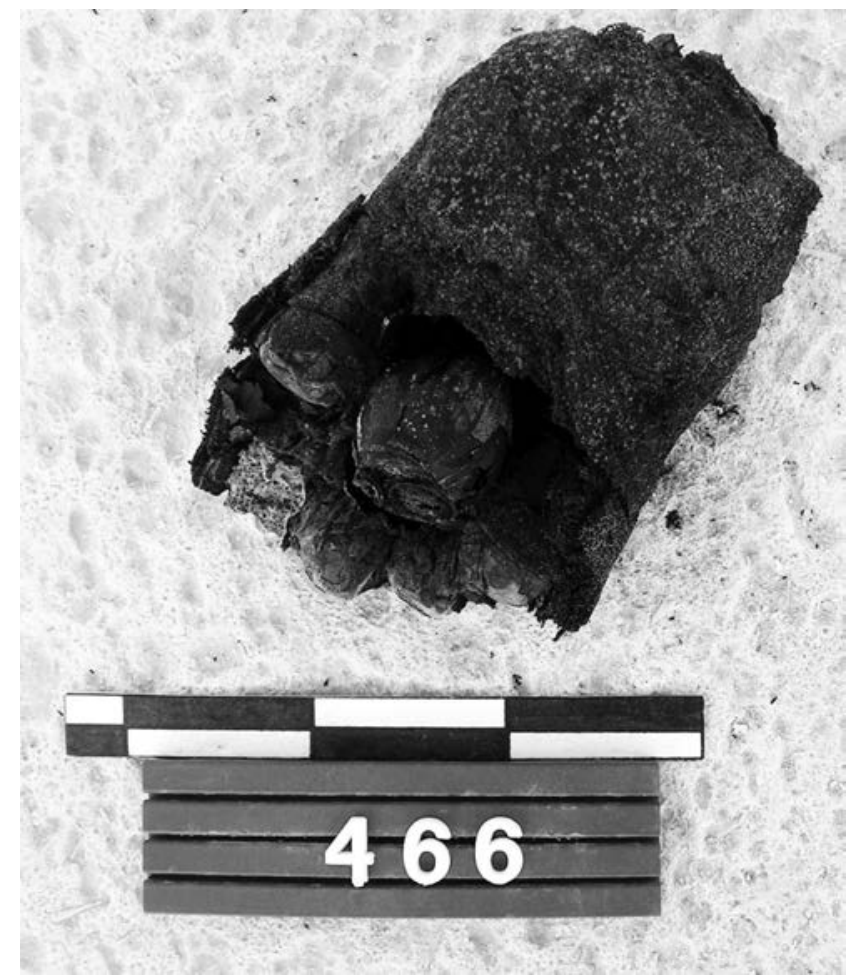

Fig. 12. Burial 466: right hand holding an onion. Linear scale is 10 $\mathrm{cm}$ (phot. I. Kozieradzka).

deposited in a grave becomes then important. The presence of onions in mummy burials may also be associated with the worship of Sokar (Grajetzki, 2004). As stated by A. Niwiński, on the eve of the main feast of this god participants in the procession had special garlands of onions made for them (Niwiński, 1992).

\section{Wooden canopic boxes and figurines}

Three of the cartonnage mummies (B. 406, 483, 529) had wooden canopic chests among their grave furnishings (Radomska et al., 2008; Myśliwiec \& Kuraszkiewicz et al., 2010). These were made of cedar wood (Cedrus libani) like two figurines of Ptah-Sokar-Osiris (B. 483 and 529) although the slats from the bottom of the chest from B. 483 were made of fir (Abies cilicica) and not cedar (Fig. 13).

\section{Packets}

Plant remains were found also inside the three bandages-wrapped packets by the mummies (B. 211, 474, 492) (Radomska et al., 2008). Paleobotanical analyses indicated that the powdered dark brown, grey or black substances were a mixture of herbs in one case (B. 211), plant remains resembling most closely finely crushed leek leaves (Allium kurrat) - in the other (B. 474), and some vegetal ashes including wheat straw (Triticum dicoccum) and fragments of grape pericarp (Vitis vinifera L.) - in the third case (B. 492). The contents of the packets seem to correspond to remains of burnt offerings and material used in the mummification process.

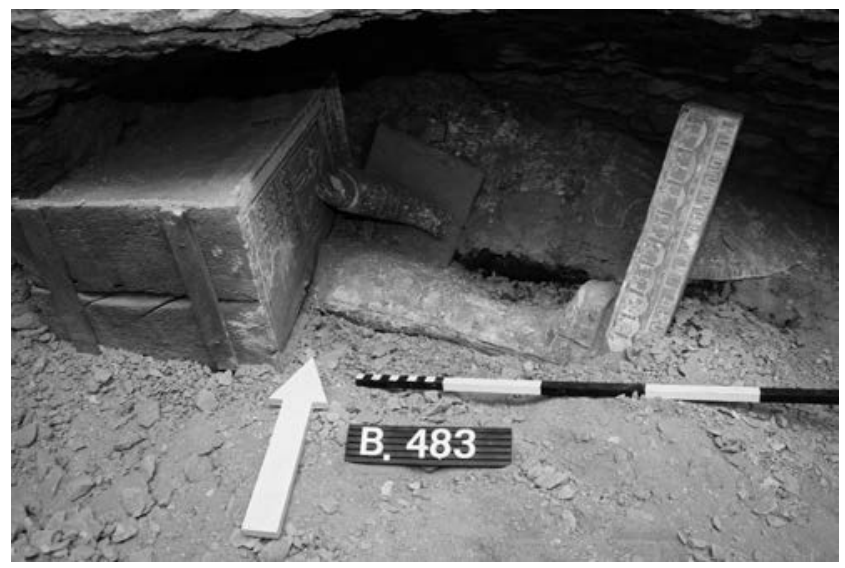

Fig. 13. Burial 483: wooden canopic chest with figurine of PtahSokar-Osiris inside the niche of funerary shaft. White arrow indicates the north direction and linear scale is $0.5 \mathrm{~m}$ (phot. P. Lelek).

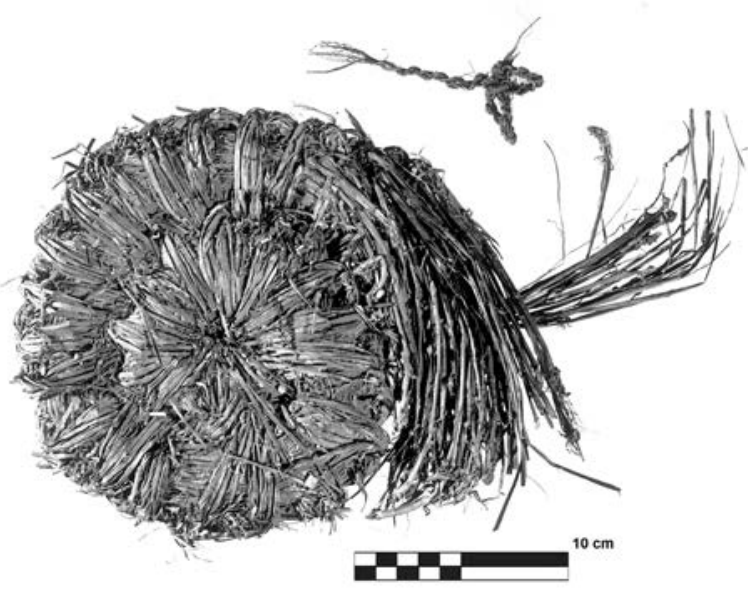

Fig. 14. Fragment of woven reed basket from Burial 183 (phot. M. Jawornicki).

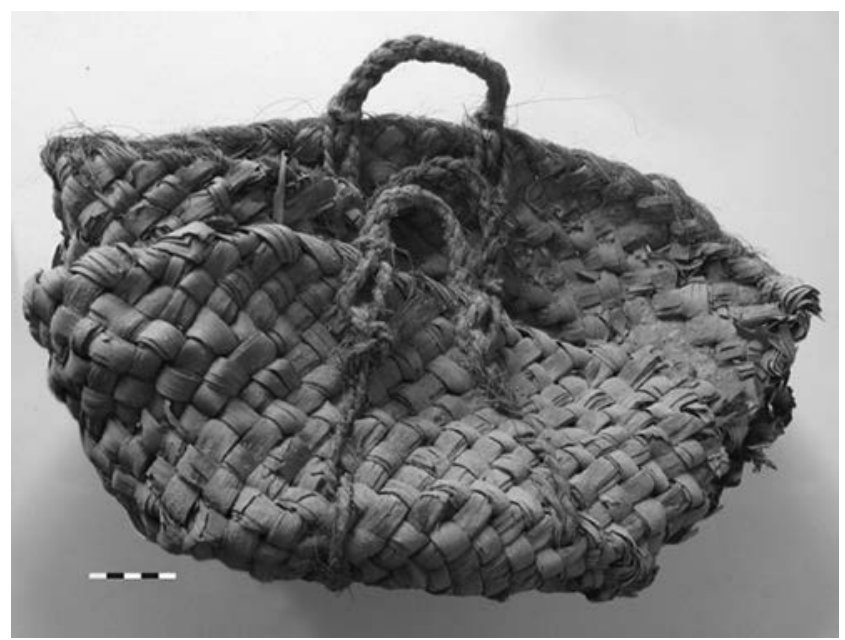

Fig. 15. Two reed baskets found under Burial 422. Linear scale is $10 \mathrm{~cm}$ (phot. J. Dąbrowski).

\section{Baskets}

Three plaited baskets found in the context of two burials (B. 183, 422) were made of pressed reeds fiber strands (Radomska et al., 2008) (Figs 14, 15). 


\section{CONCLUSIONS}

Archaeobotanical examination of plant remains from the burial contexts of the Upper Necropolis in Saqqara West allow to record and identify 14 species of plants that were deposited with the deceased in the graves. These are: fir, acacia, onion, leek, cedar, papyrus, fig, barley, palm, flax, datepalm, pomegranate, emmer wheat and grapes (Table 1, right side).

Although substantially more plant remains have been attested in layers belonging to the older cemetery (Table 1, left side), this does not mean that these particular species did not occur in the Memphite environment during the Ptolemaic Period. To date these have not been attested in the archaeological material from the Saqqara West site. The Polish research answered the question what species of plants and vegetables grew in the environs of the necropolis, making them easily accessible for burial purposes.

Study on floral remains, found in funerary contexts in the Upper Necropolis, enlarge knowledge contained in papyri sources of this period, while indicating the extraordinary diversity of Egyptian flora used in the funeral ritual in the Memphite necropolis during the reign of the Ptolemaic kings.

\section{Acknowledgements}

I am thankful to Dr. Jarosław Zieliński from the Department of Dendrology and Landscaping of Green Areas in the Agricultural Academy in Szczecin (Poland) for paleobotanical analysis of all vegetal finds and to Iwona Pannenko, head of the labs at the National Museum in Warsaw, for laboratory analysis of textile samples.

\section{REFERENCES}

Barguet, P. 1967. Le Livre des Morts des Anciens Egyptiens. Paris. Grajetzki, W. 2004. Burial Customs in Ancient Egypt: Life in Death for Rich and Poor. London.

Kaczmarek, M., Schweitzer, A., Godziejewski, Z., Pannenko, I. 2008. Saqqara III. The Upper Necropolis. II: Studies, 553-554, 559-569. Varsovie.
Kowalska, A. 2003. The Wooden Anthropoid Coffin from Burial 335. Polish Archaeology in the Mediterranean, XIV: 141.

Manniche, L. 1989. An Ancient Egyptian Herbal, 71, 107, 116, 140. London.

Myśliwiec, K. 2011. Old Kingdom coffins made of Cyperus papyrus. In: Callender, V.G., Bareš, L., Bárta, M., Janák, J., Krejči, J. (eds.), Times, Signs and Pyramids - Studies in Honour of Miroslav Verner on the occasion of his seventieth birthday, 297-306. Prague.

Myśliwiec, K., Kuraszkiewicz, K., Czerwik, D., Rzeuska, T., Kaczmarek, M., Kowalska, A., Radomska, M., Godziejewski, Z. 2004. Saqqara I. The Tomb of Merefnebef. Varsovie.

Myśliwiec, K., Kuraszkiewicz, K.O. with contributions by Kowalska, A., Radomska, M., Rzeuska, T.I., Kaczmarek, M., Kozieradzka, I., Godziejewski, Z., Ikram, S., Zatorska, A. 2010. Saqqara IV. The Funerary Complex of Nyankhnefertem, 36, 69, 98-121. Varsovie.

Niwiński, A. 1992. Myths and Symbols of Ancient Egypt (Mity i symbole starożytnego Egiptu), 216. Warszawa (in Polish).

Niwiński A. 1993. Deities, cults and rituals of Ancient Egypt (Bóstwa, kulty i rytuały starożytnego Egiptu), 209. Warszawa (in Polish).

Radomska, M., Kowalska, A., Kaczmarek, M., Rzeuska, T.I. with contributions by Kopp, E., Kuraszkiewicz, K.O, Winnicki, J.K. 2008. Saqqara III. The Upper Necropolis. I: The Catalogue with drawings, 54, 61, 88, 166, 180, 268, 289, 291, 294, 305, 316, 321, 325, 348, 352, 360, 376-377, 414. Varsovie.

Rzeuska, T. 2006. Saqqara II. Pottery of the late Old Kingdom. Funerary Pottery and Burial Customs, 469, 471-474, 478, 511512. Varsovie.

Rzeuska, T., Zieliński, J. 2004. "Beer Jars" with Ashes from Saqqara. Preliminary Report. Polish Archaeology in the Mediterranean, XIV: 153-154.

Schweitzer, A. 1992. Les parures de cartonnage des momies de Kom Ombo au musée Guimet d'histoire naturelle de Lyon. La Revue du Louvre et des Musées de France 3: 21.

Thompson, D. 1988. Memphis under the Ptolemies, 10, 38-43. Princeton.

Wipszycka, E., Bravo, B. 2010. History of the Ancient Greeks III. Hellenistic Period. (Historia starozytnych Greków III. Okres hellenistyczny), 271, 273-274. Warszawa (in Polish). 